\title{
Potential Food Safety Concerns in Fried Potato Products in Kenya
}

\author{
George 0. Abong ${ }^{*}$, Jackson N. Kabira ${ }^{2}$ \\ ${ }^{1}$ Department of Food Science, Nutrition and Technology, University of Nairobi, Nairobi (Kangemi), Kenya \\ ${ }^{2}$ National Potato Research Centre (KARI), Tigoni, Limuru, Kenya \\ Email: georkoyo@yahoo.com
}

Received 28 April 2015; accepted 14 May 2015; published 22 May 2015

Copyright (C) 2015 by authors and OALib.

This work is licensed under the Creative Commons Attribution International License (CC BY). http://creativecommons.org/licenses/by/4.0/

(c) (i) Open Access

\section{Abstract}

Fried potato products, mainly French fries and potato crisps, are consumed across all age groups and socio-economic status. These products are sources of energy and provide between-the-meal snacks for many consumers all over the world, Kenya included. There exist different food preparation set-ups that process these products under different conditions while using a variety of additives. A number of safety issues have, however, risen in the past that can be linked to glycoalkaloids in raw potatoes used during processing. Quality and content of oil used for frying are increasingly being blamed for obesity and heart diseases in the changing lifestyles currently witnessed in Kenya. Presence of acrylamide, excessive use of flavor enhancers, colorants and food additives in general have been suggested as possible contributors to increasing cases of cancer and cardiovascular diseases. Increased consumption of these products can as well lead to higher exposure of the population to possible carcinogens such as acrylamide and packaging migrants. This review analyzes the potential hazards in French fries and potato crisps processing chains taking into account the Kenyan context. The possible impact of these hazards to the general consumer is also discussed and potential areas of research and evaluation are indicated.

\section{Keywords}

Fried Potato, Toxicity, Glycoalkaloids, Additives, Acrylamide, Oxidation Products

Subject Areas: Food Science, Technology

\section{Introduction}

Potato in Kenya can be considered as a dual-purpose crop that serves both the household staple food requirement and also as a cash crop that earns income to a number of people [1]. Most of the potato produced in Kenya

"Corresponding author. 
is used in home preparations, French fries, potato crisps and to small extent frozen French fries. Utilization of potato has increased all over the world and has become a major staple, especially in Kenya where it is currently ranked second to maize [2] [3]. Consumption of fried potato products has been on the increase worldwide [4]. Many households in potato growing zones and some urban centres use potato in stew and as an important accompaniment to many dishes. Potato crisps and French fries are the most important potato products that are industrially produced and consumed by a larger proportion of Kenyans, mainly in urban centers. Due to increased consumption, crisps, for instance, have assumed a high position in the snack industry and hence large share in the supermarkets, kiosks and roadside shops [5]. On the other hand, French fries have become the most popular lunch time meal for people of all socio-economic classes. The low income and middle class earners have made French fries to be almost a daily food, especially those in the urban areas where harsh economic conditions have driven many people to seek inexpensive alternatives. Moreover, these products are most convenient for the young generation who do not prepare own food, and have unique appealing sensory properties [6].

Cases of lifestyle diseases such as cancer, obesity and diabetes have been on the increase all over the world and Kenya is not an exception [7]. In search for solutions to these teething problems, many people have pointed fingers to changes in lifestyle with major emphasis being placed on foods. Food safety concerns have therefore focused not only on what foods to eat, but also those foods which consumers need to avoid [8]. Due to awareness that has been created by consumer federation and media, fried potato products such as potato crisps and French fries have received most of the blame in any given forum. This paper focuses on potential food safety concerns along the potato crisps and French fries chains in Kenya both in formal retail and street processed products.

\section{Potential Hazards in French Fries and Potato Crisps Processing Chains}

There exist different food preparation set-ups on French fries and potato crisps products under different conditions while using a variety of additives. A number of safety issues have, however, been raised in the past that are linked to glycoalkaloids in potatoes used during processing, oil quality, flavor and color enhancers, acrylamide and packaging migrants. Figure 1 and Figure 2 illustrate the process flow diagrams for French fries and potato crisps in Kenya (Authors' unpublished survey). Careful observation of each step indicates processing steps, some of which require careful consideration to prevent hazards that are likely to occur along the chains.

\subsection{Pre-Processing Operations}

Potatoes should be harvested at full maturity when they have attained a high level of dry matter and low reducing sugars [9] [10]. Physiologically mature potato tubers are not easily injured during handling and transportation. Due to financial pressure, most potato farmers in Kenya are forced to harvest immature tubers which are sold immediately to obtain cash income [11]. This means most of the tubers have high reducing sugars, a major factor in acrylamide formation during frying.

Harvested tubers should be cured at high temperature and humidity $\left(12^{\circ} \mathrm{C}-25^{\circ} \mathrm{C} / 85 \%\right.$ - 95\% RH) to facilitate healing of wounds incurred during harvesting. The operation also helps the wet tubers to dry off. Unlike large scale processors who have organized stores, most small scale processors who make up at least $80 \%$ purchase raw tubers from open air markets which sell immature and non-cured tubers [5]. In most cases potatoes are harvested and taken to the market immediately. Poor potato packaging and handling of large bags above the legal limit of $110 \mathrm{~kg}$ and exposure of potatoes to sunlight which is common in Kenyan markets are practices which greatly increase the risk of exposure to glycoalkaloids [12] [13]. High chances of buying greened immature tubers and hence accumulated glycoalkaloids is very likely in the local cultivars [14]. Raw material selection by a few large scale processors is done on the basis of size, reducing sugars and specific gravity while small processors who have no means of ascertaining these parameters select tubers visually based on tuber size and color preference, whether red or white skinned [5].

\subsection{Sorting}

Sorting plays a critical role by removing very thin slices or sticks which easily burn off and make the frying oil dirty facilitating quality degradation. It is also a process meant to remove defective and greened pieces. Sorting in large processing set-ups is carried out immediately after frying to remove either greened or dark brown slices 


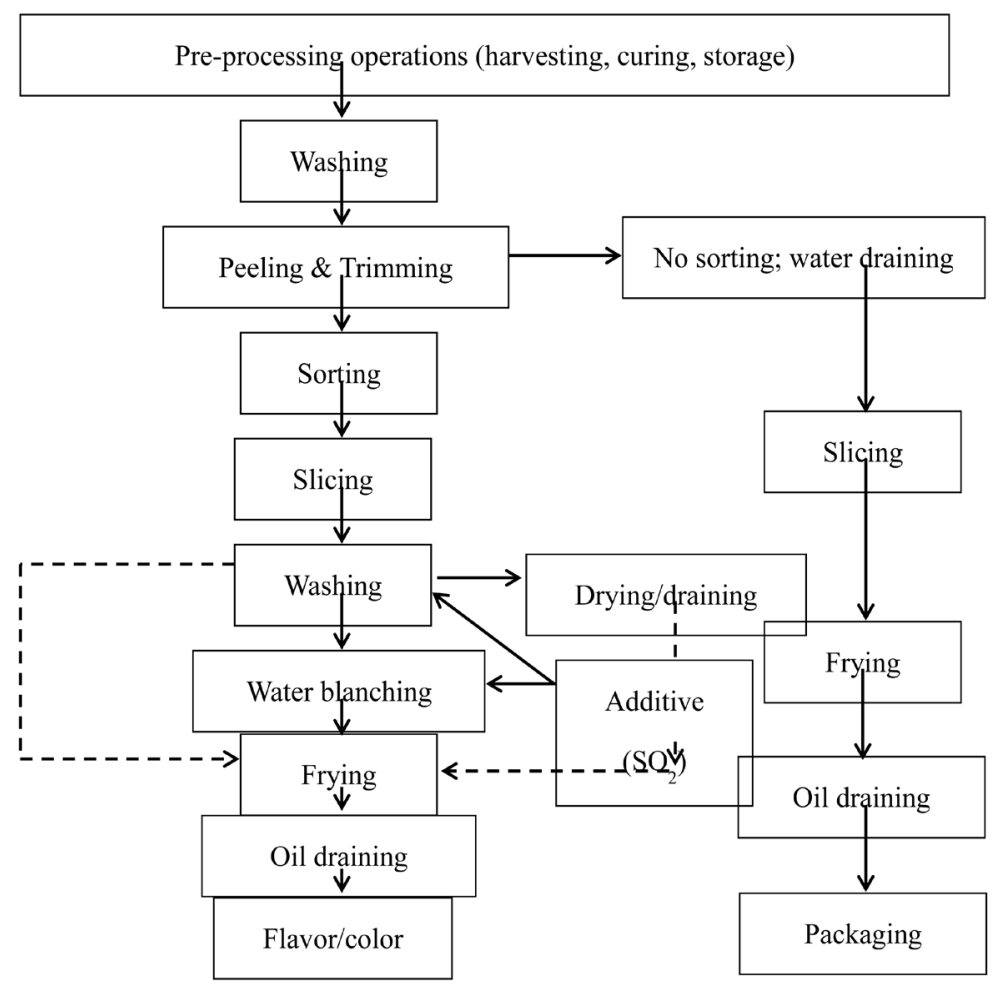

Figure 1. General processing flow sheet for Kenyan potato crisps by large, medium scales and street processors.

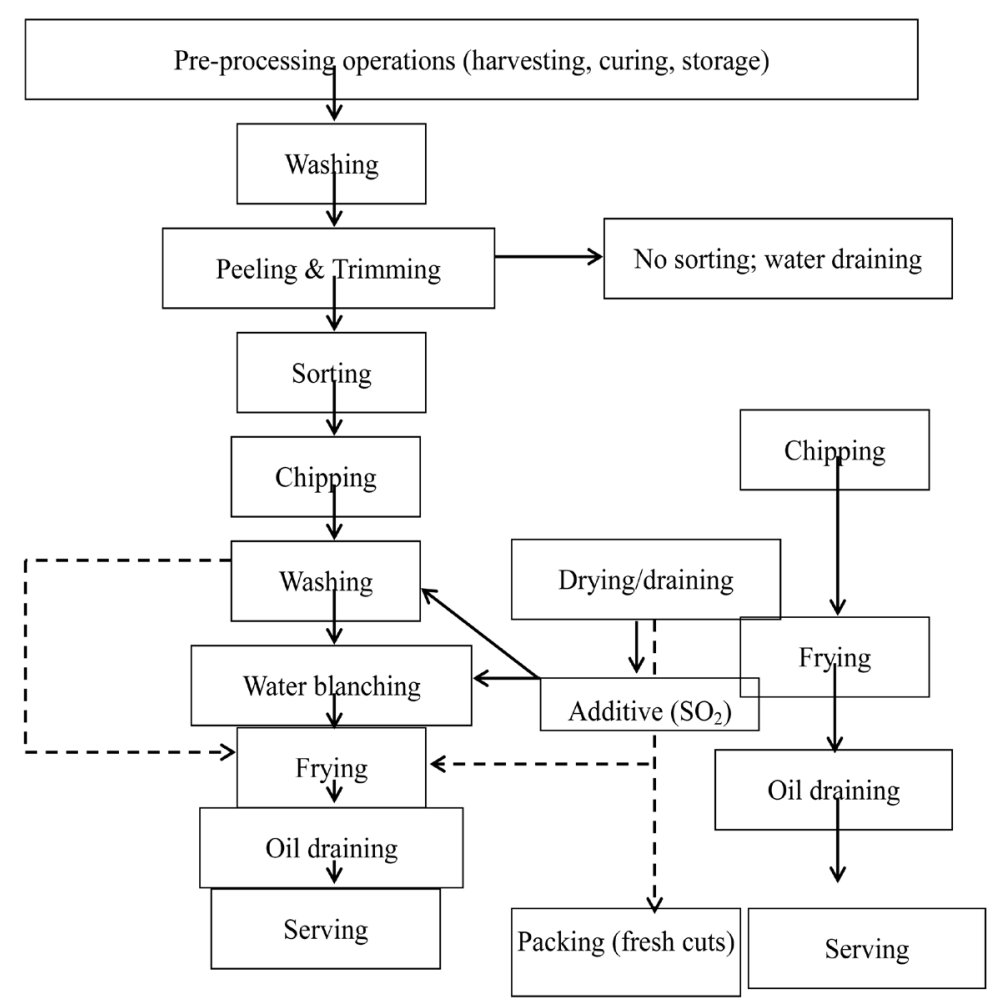

Figure 2. General processing flow sheet for French fries by hotels, cafeterias and street processors in Nairobi Kenya. 
of crisps. It is, however, rarely carried out in the street and cafeteria processing. It is therefore common to find many greened and dark brown pieces of fries or crisps in the final product [5]. Dark brown colored crisps are often masked by application of colorants. This may be an avenue of exposing consumers to high levels of glycoalkaloids and acrylamide.

\subsection{Washing, Blanching and Sulfur Dioxide Treatment}

Washing is usually done to remove excess starch that is exposed due to rupture of potato tuber tissues in order to avoid making the frying oil dirty and reduce the rate of breakdown. Blanching either in water or oil ensures light colored fried products following extraction of reducing sugars and asparagine which are known to interact to produce acrylamide [10]. For most small scale processors, washing takes very short time and blanching is not common and hence the increased probability of producing high acrylamide fries. On the other hand, medium and large scale producers have to hold the chipped or sliced raw potatoes for longer duration before frying and hence employ the use of anti-browning agents such as sodium metabisulfite instead of blanching which is considered as an added cost. The use of sulfur dioxide is gaining momentum especially due to increased production and sale of "fresh cut" French fries which are prepared by chipping, soaking in sulfur containing water, draining and packaging. Indiscriminate use of this chemical in processing plants can be a health hazard.

\subsection{Frying Process and Frying Oil}

Frying of potato crisps and French fries in Kenya is carried out under varied conditions with limited controls. Large scale crisps processors and most medium to large hotels who sell fries have adequate temperature controlled equipment which is lacking among small processors, chips (French fries) joints and street food dealers makers who make up a sizable proportion. Use of higher than necessary and unregulated temperatures for frying is therefore not uncommon; this may lead to extremely high levels of acrylamide in the final product given the fact that the tubers used could be high in reducing sugars as well. Almost all crisps producers use liquid oil for frying, generally palm oil based [5] [15]. On the other hand, majority of French fries producers use solid fats which are either hydrogenated or non-hydrogenated. Interestingly, replacement of frying oils is quite dependent on the set-up; most (70\%) establishments replace oil daily, while other set-ups (27\%) can use the same oil continuously for about 2 - 4 days (authors unpublished data). Although the majority of processors discard spent oil, a good number use it for frying other snacks such as ground nuts, doughnuts and sausages [5]. Chances of producing fried products with high levels of polycyclic triacylglycerides and trans fatty acids is therefore highly likely.

\subsection{Flavor Enhancers and Colorants}

Different flavors and colorants are applied to fried potato products after frying mainly to enhance their palatability and taste. A number of flavored crisps exist in Kenyan retail market ranging from plain salted, cheese and onion, tomato and so on [5]. The type and amounts of these flavors depend on the producer especially in cases where street products are concerned. Customers may therefore be consuming higher than recommended amounts coupled with the fact that their microbial diversity and loads are not known. French fries are normally served immediately after frying in many set-ups and the consumer adds at will the diluted tomato and hot (chilli) sauces whose hygiene standards are not ascertained.

\subsection{Packaging}

Potato crisps are mainly packaged in polyethylene plastic bags which vary in make and thickness, while a few brands are packaged in aluminium packs. On the other hand, the hot-served French fries are packaged in polyethylene bags and different types of paper including plain paper. Studies on migration of packaging materials into these products have not been carried out in Kenya, but this may be a potential hazard.

\section{Safety Concerns Related to Potato Crisps and French Fries}

In the recent past, many cases of obesity, cancer and related toxicological disorders have been reported in Kenya that has left health sector worried [7] [16]. The disease cuts across all ages and continues to claim many lives 
with worldwide estimated deaths of at least 10 million in the next decade if not properly controlled [17]. The high numbers of cancer cases have left both health practitioners and nutritionists baffled even as Government officials and researchers continue to look for answers. Among the factors which have been associated with these cases include changing lifestyle, pollution, climate changes and the foods being consumed. Many complaints have been directed towards fried potato products with most fingers being pointed at French fries and potato crisps.

Potential risk of glycoalkaloids intoxication is high due to increased consumption of potato and potato products some of which are transported, handled and poorly stored. Poor infrastructure combined with lack of proper storage facilities often lead to injury and greening and hence increased levels of glycoalkaloid [18]. Though the available information is scanty and sometimes unavailable, the limited information indicates that a number of potato crisps brands in Kenyan market have higher than the recommended East African Standards [19] maximum limit of 35\% oil content [5]. The type of oil influences the amount absorbed and resultant products of frying [20]. Moreover, different flavor enhancers and colorants are used in French fries and potato crisps, some of which may be harmful when indiscriminately used [21].

French fries and potato crisps have been known to have high levels of acrylamide ever recorded in research so far [22]-[24]. Acrylamide formation has been linked to Maillard reaction, resulting to browning of fried products. Lack of data on this subject makes it hard to conclude on exposure of acrylamide to Kenyan population. However, extremely brown potato crisps available in market outlets, many of which are laced with colorants, could be an important pointer to this effect [5].

\subsection{Occurrence of Glycoalkaloids in Potato}

The glycoalkaloids in potatoes are natural toxic substances with alpha-solanine and alpha-chaconine being the most predominant [25]. Solanine content varies with potato variety since it is genetically controlled; values in European and United States have been reported to range from 2 to $15 \mathrm{mg}$ per $\mathrm{kg}$ of unpeeled tubers [26]. However, regional and geographical conditions influence the levels of glycoalkaloids. Injuries during harvesting and poor post-harvest handling practices such as exposing potato tubers to sunlight increase the levels of glykoalkaloids with high concentration in the skin [27]. It is generally agreed that the best raw potato for processing should not have more than $20 \mathrm{mg}$ total glycoalkaloids (TGA) in $100 \mathrm{~g}$ of tuber [28]. Higher levels beyond 100 $\mathrm{mg} / \mathrm{kg}$ are potentially dangerous; some countries have even set the upper limit to be $10 \mathrm{mg} / 100 \mathrm{~g}$ sample [29]. Susceptibility of humans to side effects of glycoalkaloids has been shown to be very high and varies from person to person [30]. It has been shown that an oral daily intake of $1-5 \mathrm{mg} / \mathrm{kg}$ body weight can have marginal or severe toxic effects to humans [31]. Consumption of high levels of glycoalkaloids has been associated with negative health effects such as gastrointestinal discomfort, vomiting, fever, diarrhea and neurological problems and can lead to human or animal deaths in cases of acute toxicity [32] [33]. Glycoalkaloids are normally heat stable and hence only limited reduction may be achieved during processing and it becomes even more difficult when tubers have high accummulations [34] [35]. Large scale glycoalkaloid poisoning is rare though mild poisoning is suspected to be more prevalent than many can imagine [36]. Difficulty in diagnosis of poisoning is compounded by the fact that symptoms of toxicity are similar to other gastrointestinal disorders [37].

The toxic action of Glycoalkaloids may be two folds. First, it may affect the cell membrane by disrupting the phosphatidylcholine or cholesterol liposomes at higher concentrations of $50 \mu \mathrm{Mol}$ [38]. Glycoalkaloids have been shown in animal studies to negatively affect intestinal permeability and long term exposure could lead to chronic inflammatory disease of the bowel [39] [40]. Secondly, it can also act to inhibit acetylcholinesterase both in humans and bovine especially at higher levels of $100 \mu \mathrm{Mol}$ [41]. Both chronic and acute toxicity of glycoalkaloids are possible [42].

In a study conducted by Kirui et al. [14] to quantify levels of total glycoalkaloids selected Kenyan varieties and advanced clones, the levels were found to range from 3.5 to $17.5 \mathrm{mg} / 100 \mathrm{~g}$, which was in the normal range of less than $20 \mathrm{mg} / 100 \mathrm{~g}$. Results from other researchers in different countries are given in Table 1 . These results of Kirui et al. [14] were, however, obtained by analyzing tubers under well controlled field experimentation and storage at the National Potato Research Centre, potential risk of glycoalkaliod toxicity may be high due to increased consumption of potato and potato products, some of which are transported or handled poorly. Poisoning of animals that are fed greened tubers and peels remain to be assessed. 
Table 1. Reported total glycoalkaloid contents in potato and potato products ${ }^{1}$.

\begin{tabular}{ccccc}
\hline Product & Continent & Country & Levels (mg/100 g) & Source \\
\hline Raw tubers & Europe & France & $11-62$ & Arkhypova et al. [26] \\
Raw tubers & Europe & Poland & $20-27$ & Rytel [25] \\
Dried potatoes & Europe & Poland & $9.9-10.7$ & Rytel [25] \\
Raw tubers & Europe & Germany & $2-35$ & Haase [36] \\
Raw tubers & Europe & Denmark & $4-156$ & Knuthsen et al. [29] \\
Raw tubers & Africa & Kenya & $3.5-17.5$ & Aziz et al. [14] $[34]$ \\
Raw tubers (peel) & Asia & Pakistan & $177-5449$ & Aziz et al. [34] \\
Raw tubers (flesh) & Asia & Pakistan & $3-491$ & Ji et al. [43] \\
Raw tubers & N. America & Canada & $0.01-6.85$ & \\
\hline
\end{tabular}

${ }^{1}$ Low and high ranges from literature.

\subsection{Frying Oil and Oxidation Products}

Deep fat frying is generally adopted as a fast and convenient way of producing foods acceptable to large number of consumers. Oil used during food preparation determines the food flavor, stability, texture and taste. There are, however, several concerns that have been raised regarding deep fat fried foods. Firstly, the amount of oil absorbed by frequently consumed foods such as potato crisps and French fries has been a major point of debate since the oil absorbed during processing becomes part of the diet [6] [44]. Many nutritionists have blamed these high energy food products as major causes of obesity [45] and cardiovascular disease [46] [47]. A number of potato crisps brands in Kenyan market, for instance, were found to have higher than the recommended East African Standards maximum limit of 35\% oil content [5] [19].

Secondly, it is a well-established fact that some compounds formed during frying potentially toxic which are responsible for physical and chemical changes in frying oil pose great danger to human health [48]. Due to high temperatures normally used, break down of frying oil leads to formation of dangerous compounds such as polymerized triacylglycerol, trans fatty acids, conjugated dienes and oxidation products [45] [49]. High levels of phytosterol oxidation products (POPs) have been detected in French fries samples from restaurant being related to higher contents of fat, saturated and monounsaturated fatty acids and sterols [50]. POPs and other sterol epoxides formed during frying depend on frying temperature, fatty acid composition and phytosterol contents of individual oil used in frying and have been found to be high in some restaurants as well as French fries also in Sweden which may pose risk to consumers [51] [52]. Such studies are yet to be carried out in Kenya to ascertain the extent of their occurrence especially when frying oils are abused. Observation of proper frying time or turnover is critical to ensure safety of fried products.

\subsection{Additives, Color Enhancers and Sauces}

For sometimes now risks due to abuse or extensive and indiscriminate use of food additives have become major food safety concerns [53]. The risks arising from food additives are considered invisible and may be seen as a violation of consumer safety rights [54]. Major groups of food additives extensively used in foods include preservatives, color, flavor enhancers, and spices. Exposure of sulfite to Kenyan consumers remains unknown due to lack of adequate evaluation and control systems. However, sulfite has been associated with negative health effects especially for ready to eat foods since it causes asthmatic reactions and may also affect the nervous system in some individuals [55] [56]. Different flavor enhancers and colors are also used in French fries and potato crisps some of which may be harmful when indiscriminately used [57] [58]. The actual level of exposure remains unknown due to lack of evaluation.

Microbial contamination of sauces and salads used in restaurants serving French fries has been reported in other parts of the world. Contamination from Escherichia coli, Staphylococcus aureus, Bacillus cereus, Salmonella and other pathogens known to cause serious illnesses have been reported in the United Kingdom [59]. 
Fungal and bacterial contamination of herbs has also been reported in other parts of the world [60]. In light of unregulated street food preparation some of which are unhygienic, likelihood of contamination of sauces and fries is high [61]. Since these sauces are consumed directly without further heating, their impact on human health can be deleterious.

\subsection{Acrylamide in Potato Crisps and French Fries}

Discovery of acrylamide in fried products has raised serious food safety concerns the world over [62]. Acrylamide is a chemical that remains a suspect human carcinogen and a neurotoxicant with adverse effects on normal metabolism [63] [64]. Depending on the amount and type of food being consumed by an individual, carcinogenic and genotoxic risks due to acrylamide in the diet vary considerably [65]. High levels of acrylamide up to 4565 ppm have been reported in Kenyan potato crisps [66]. The current high values are beyond the indicative value of 1000 ppm given for other countries and regulatory bodies such as the European Food Safety Authority [67] and other researchers worldwide (Table 2). Surveys carried out in many parts of the world indicate higher exposure of acrylamide especially from French fries and potato crisps. Total diet study in France, for instance, indicated lower exposure margins for children [24]. Exposure to acrylamide via fried potato products have been reported in Belgium [68], Italy [69] and Norwegian population [70]. Due to high consumption of the fried potato products in Kenya, mainly the urban dwellers, exposure to acrylamide could be high and so is the likelihood of contribution to negative health effects. Proper mitigation measures would involve capacity building along the chain from production and harvesting practices to storage and processing.

\subsection{Migrants from Packaging Materials}

Studies on migration of packaging material components into foods have not been carried out in Kenya, but it remains a potential hazard. Chemical migrants, however, will depend on the type and amount of food, temperature and molecular size of the chemical in packaging material [77] [78]. The negative effects of these migrants to food safety can no longer be over looked if safety of the food supply is to be assured [79]. Chemical migrants from polyethylene in both simulants and true foods have been reported in Europe, being high in oily foods under higher temperature [80] [81]. Similar trends have been reported in Brazil [82]. Since French fries are packaged in polyethylene and papers while hot, risks of consuming high levels of migrants cannot be overemphasized.

\section{Conclusion and Prospect}

Increasing research findings across the world continues to expose dangers associated with unregulated handling

Table 2. Reported values of acrylamide contamination in the world.

\begin{tabular}{ccccc}
\hline Food type & Contamination $(\boldsymbol{\mu g} / \mathbf{k g})$ & Country & Continent & Author \\
\hline Baby foods & $2-516$ & Poland & Europe & Mojska et al. [71] \\
Potato crisps & $244-1688$ & Iran & Asia & Boroushaki et al. [72] \\
Potato crisps & $30-2300$ & Sweden & Europe & Tareke et al. [73] \\
Potato crisps/chips & $27-1400$ & Italy & Europe & Tateo et al. [69] \\
Potato crisps & $2311^{\mathrm{m}}$ & Belgium & Europe & Douny et al. [68] \\
Potato crisps & $707^{\mathrm{m}}$ & Belgium & Europe & Mestdagh et al. [65] \\
Potato crisps & $954^{\mathrm{m}}$ & France & Europe & Sirot et al. [24] \\
French fries & $724^{\mathrm{m}}$ & France & Europe & Sirot et al. [24] \\
Potato crisps & $59-2336$ & Turkey & Europe & Olmez et al. [74] \\
Potato crisps & $40-1770$ & Chile & S. America & Pedreschi et al. [23] \\
Potato crisps & $720^{\mathrm{m}}$ & Ireland & Europe & Cummins et al. [75] \\
French fries/crisps & $117-2762$ & USA & North America & FDA [76] \\
\hline
\end{tabular}

\footnotetext{
${ }^{\mathrm{m}}$ Average values.
} 
and processing of fried potato products and consumers are increasingly becoming aware of the need to eat healthy foods. Research institutions and Government agencies must step up efforts to acquire data in regard to exposure of the general public to negative components or by-products in foods that have been associated with non-communicable diseases. There is a need for Kenya to invest in risk analysis and strict control of foods that are meant for consumption by the citizens in order to build an information data base.

\section{References}

[1] Gildemacher, P.R., Kaguongo, W., Ortiz, O., Tesfaye, A., Woldegiorgis, G., Wagoire, W.W., Kakuhenzire, R., Kinyae, P.M., Nyongesa, M., Struik, P.C. and Leeuwis, C. (2009) Improving Potato Production in Kenya, Uganda and Ethiopia: A System Diagnosis. Potato Research, 52, 173-205. http://dx.doi.org/10.1007/s11540-009-9127-4

[2] Nema, P.K., Ramayya, N., Duncan, E. and Niranjan, K. (2008) Potato Glycoalkaloids: Formation and Strategies for Mitigation. Journal of the Science of Food and Agriculture, 88, 1869-1881. http://dx.doi.org/10.1002/jsfa.3302

[3] Ministry of Agriculture (MoA) (2009) Mainstreaming the Potato Crop from Orphan Crop Status. Proceedings of Round Table Africa (RTA) Potato Stakeholders' Workshop, Nairobi, 8 May 2009.

[4] Peksa, A., Gołubowska, G., Aniołowski, K., Lisińska, G. and Rytel, E. (2006) Changes of Glycoalkaloids and Nitrate Contents in Potatoes during Chip Processing. Food Chemistry, 97, 151-156. http://dx.doi.org/10.1016/j.foodchem.2005.03.035

[5] Abong', G.O., Okoth, M.W., Imungi, J.K. and Kabira, J.N. (2010) Consumption Patterns, Diversity and Characteristics of Potato Crisps in Nairobi, Kenya. Journal of Applied Biosciences, 32, 1942-1955.

[6] Chiou, A., Kalogeropoulos, N., Boskou, G. and Salta, F.N. (2012) Migration of Health Promoting Microconstituents from Frying Vegetable Oils to French Fries. Food Chemistry, 133, 1255-1263. http://dx.doi.org/10.1016/j.foodchem.2011.08.068

[7] American Society of Clinical Oncology (ASCO) (2012) Cancer in Kenya. http://www.asco.org/

[8] Lee, G.-I., Lee, H.-M. and Lee, C.-H. (2012) Food Safety Issues in Industrialization of Traditional Korean Foods. Food Control, 24, 1-5. http://dx.doi.org/10.1016/j.foodcont.2011.09.014

[9] Abong, G.O., Okoth, M.W., Karuri, E.G., Kabira, J.N. and Mathooko, F.M. (2009) Levels of Reducing Sugars in Eight Kenyan Potato Cultivars as Influenced by Stage of Maturity and Storage Conditions. Journal of Animal and Plant Sciences, 2, 76-84.

[10] Elfnesh, F., Tekalign, T. and Solomon, W. (2011) Processing Quality of Improved Potato (Solanum tuberosum L.) Cultivars as Influenced by Growing Environment and Blanching. African Journal of Food Science, 5, 324-332.

[11] Walingo, A., Lung'aho, C., N'gang'a, N., Kinyae, P.M. and Kabira, J.N. (2004) Potato Marketing, Storage, Processing and Utilization in Kenya. Proceedings of the 6th Triennial Congress of the African Potato Association, Agadir, 5-10 April 2004, 24-42.

[12] Machado, R.M.D., Toledo, M.C.F. and Garcia, L.C. (2007) Effect of Light and Temperature on the Formation of Glycoalkaloids in Potato Tubers. Food Control, 18, 503-508. http://dx.doi.org/10.1016/j.foodcont.2005.12.008

[13] Lisinska, G., Peksa, A., Kita, A., Rytel, E. and Tajner-Czopek, A. (2009) The Quality of Potato for Processing and Consumption. In: Yee, N. and Bussel, W., Eds., Potato for Food, Volume 2, Instytutu Hodowli, Belgium, 99-104.

[14] Kirui, K.G., Misra, A.K., Olanya, O.M., El-Bedewy, R., Ewell, P.T. and Friedman, M. (2009) Glycoalkaloid Content of Some Superior Potato (Solanum tuberosum L.) Clones and Commercial Varieties. Archives of Phytopathology and Plant Protection, 42, 453-463. http://dx.doi.org/10.1080/03235400601164505

[15] Walingo, A.M., Alexandre, C., Kabira, J.N. and Ewell, P.T. (1998) Potato Processing in Nairobi Kenya: Current Status and Potential for Further Development. Working Paper No. 1997-6, International Potato Centre, Nairobi.

[16] Government of Kenya (GoK) (2011) National Assembley Policy Brief on Situation Analysis of Cancer in Kenya. Government Printer, Nairobi.

[17] PACT Kenya (2011) Cancer Assessment in Africa and Asia Report. www.cancer.iaea.org

[18] Gachango, G., Shibairo, S., Kabira, J.N., Chemining’wa, G. and Demo, P. (2008) Effects of Light Intensity on Quality of Potato Seed Tubers. African Journal of Agricultural Research, 3, 732-739.

[19] EAS 745 (East African Standards) (2010) Potato Crisps-Specifications.

[20] Al-Khusaibi, M., Gordon, M.H., Lovegrove, J.A. and Niranjan, K. (2012) Frying of Potato Chips in a Blend of Canola Oil and Palm Olein: Changes in Levels of Individual Fatty Acids and Tocols. International Journal of Food Science and Technology, 47, 1701-1709. http://dx.doi.org/10.1111/j.1365-2621.2012.03024.X

[21] Adriana, S.-V., Ashley, G., Jack, N.L., Xu, Z.M. and Finley, J.W. (2012) Evolution of Phenolic Compounds from Color and Flavor Problems to Health Benefits. Journal of Agricultural and Food Chemistry, 60, 6658-6677.

http://dx.doi.org/10.1021/jf300861c 
[22] Fan, X. and Mastovska, K. (2006) Effectiveness of Ionizing Radiation in Reducing Furan and Acrylamide Levels in Foods. Journal of Agricultural and Food Chemistry, 54, 8266-8270. http://dx.doi.org/10.1021/jf061151+

[23] Pedreschi, P., Granby, B. and Risum, J. (2010) Acrylamide Mitigation in Potato Chips by Using NaCl. Food Bioprocess Technology, 3, 917-921. http://dx.doi.org/10.1007/s11947-010-0349-x

[24] Sirot, V., Hommet, F., Tard, A. and Leblanc, J.C. (2012) Dietary Acrylamide Exposure of the French Population: Results of the Second French Total Diet Study. Food and Chemical Toxicology, 50, 889-894. http://dx.doi.org/10.1016/j.fct.2011.12.033

[25] Rytel, E. (2012) Changes in Glycoalkaloid and Nitrate Content in Potatoes during Dehydrated Dice Processing. Food Control, 25, 349-354. http://dx.doi.org/10.1016/j.foodcont.2011.10.053

[26] Arkhypova, V.N., Dzyadevych, S.V., Jaffrezic-Renaul, N., Martelet, C. and Soldatkin, A.P. (2008) Biosensors for Assay of Glycoalkaloids in Potato Tubers. Applied Biochemistry and Microbiology, 44, 347-352. http://dx.doi.org/10.1134/S0003683808030162

[27] Jens, M., Harshadrai, R., Lothar, W. and Kroh, L.W. (2009) Composition of Phenolic Compounds and Glycoalkaloids Alpha-Solanine and Alpha-Chaconine during Commercial Potato Processing. Journal of Agricultural and Food Chemistry, 57, 6292-6297. http://dx.doi.org/10.1021/jf901066k

[28] Ginzberg, I., Tokuhisa, J.G. and Veilleux, R.E. (2009) Potato Steroidal Glycoalkaloids: Biosynthesis and Genetic Manipulation. Potato Research, 52, 1-15. http://dx.doi.org/10.1007/s11540-008-9103-4

[29] Knuthsen, P., Jensen, U., Schmidt, B. and Larsen, K. (2009) Glycoalkaloids in Potatoes: Content of Glycoalkaloids in Potatoes for Consumption. Journal of Food Composition and Analysis, 22, 577-581. http://dx.doi.org/10.1016/j.jfca.2008.10.003

[30] Ruprich, J., Rehurkova, I., Boon, P.E., Svensson, K., Moussavian, S., Van der Voet, H., Bosgra, S., Van Klaveren, J.D. and Busk, L. (2009) Probabilistic Modelling of Exposure Doses and Implications for Health Risk Characterization: Glycoalkaloids from Potatoes. Food and Chemical Toxicology, 47, 2899-2905. http://dx.doi.org/10.1016/j.fct.2009.03.008

[31] Hellenas, K.E., Nyman, A., Slanina, P., Loof, L. and Gabrielsson, J. (1992) Determination of Potato Glycoalkaloids and Their Aglycone in Blood Serum by High-Performance Liquid Chromatography: Application to Pharmacokinetic Studies in Humans. Journal of Chromatography Biomedical Applications, 573, 69-78. http://dx.doi.org/10.1016/0378-4347(92)80476-7

[32] Woolfe, J.A. (1987) The Potato in the Human Diet. Cambridge University Press, Cambridge. http://dx.doi.org/10.1017/CBO9780511753435

[33] Langkildea, S., Mandimika, T., Schrøder, M., Meyer, O., Slob, W., Peijnenburg, A. and Poulsen, M. (2009) A 28-Day Repeat Dose Toxicity Study of Steroidal Glycoalkaloids, $\alpha$-Solanine and $\alpha$-Chaconine in the Syrian Golden Hamster. Food Chemistry and Toxicology, 47, 1099-108. http://dx.doi.org/10.1016/j.fct.2009.01.045

[34] Aziz, A., Randhawa, M.A., Butt, M.S., Asghar, A., Yasin, M. and Shibamoto, T. (2012) Glycoalkaloids ( $\alpha$-Chaconine and $\alpha$-Solanine) Contents of Selected Pakistani Potato Cultivar and Their Dietary Intake Assessment. Journal of Food Science, 77, 58-61. http://dx.doi.org/10.1111/j.1750-3841.2011.02582.x

[35] Haddadin, M.S.Y., Humeid, M.A., Quaroot, F.A., and Robinson, R.K. (2001) Effect of Exposure to Light on the Solanine Content of Two Varieties of Potato (Solanum tuberosum) Popular in Jordan. Food Chemistry, 73, 205-208. http://dx.doi.org/10.1016/S0308-8146(00)00279-X

[36] Haase, N.U. (2008) Healthy Aspects of Potatoes as Part of the Human Diet. Potato Research, 51, $239-258$. http://dx.doi.org/10.1007/s11540-008-9111-4

[37] Smith, D.B., Roddick, J.G. and Jones, J.L. (1996) Potato Glycoalkaloids: Some Unanswered Questions. Trends Food Science and Technology, 7, 126-131. http://dx.doi.org/10.1016/0924-2244(96)10013-3

[38] Roddick, J.G., Rijnenberg, A.L. and Weissenberg, M. (1990) Membrane-Disrupting Properties of the Steroidal Glycoalkaloids Solasonine and Solamargine. Phytochemistry, 29, 1513-1518. http://dx.doi.org/10.1016/0031-9422(90)80111-S

[39] Krasowski, M.D., Mcgehee, D.S. and Moss, J. (1997) Natural Inhibitors of Cholinesterases: Implications for Adverse Drug Reactions. Canadian Journal of Anesthesia, 44, 525-534. http://dx.doi.org/10.1007/BF03011943

[40] Patel, B., Schutte, R., Sporns, P. and Fedorak, R.N. (2001) Glycoalkaloids Ingested from Potatoes Adversely Affect Intestinal Permeability and Aggravate Inflammatory Bowel Disease. Gastroenterology, 120, A186- A234. http://dx.doi.org/10.1016/S0016-5085(01)80922-7

[41] Jbilo, O., Bartels, C.F., Chatonnet, A., Toutant, J.P. and Lockridge, O. (1994) Tissue Distribution of Human Acetylcholinesterase and Butyrylcholinesterase Messenger RNA. Toxicon-Oxford, 32, 1445-1457. http://dx.doi.org/10.1016/0041-0101(94)90416-2

[42] Mensinga, T.T., Sips, A.J.A.M., Rompelberg, C.J.M., Van Twillert, K., Meulenbelt, J., Van den Top, H.J. and Van 
Egmond, H.P. (2005) Potato Glycoalkaloids and Adverse Effectsin Humans: An Ascending Dose Study. Regulatory Toxicology and Pharmacology, 41, 66-72. http://dx.doi.org/10.1016/j.yrtph.2004.09.004

[43] Ji, X., Rivers, L., Zielinski, Z., Xu, M., MacDougall, E., Stephen, J., Zhang, S., Wang, Y., Chapman, R.G., Keddy, P., Robertson, G.S., Kirby, C.W., Embleton, J., Worrall, K., Murphy, A., De Koeyer, D., Tai, H., Yu, L., Charter, E. and Zhang, J. (2012) Quantitative Analysis of Phenolic Components and Glycoalkaloids from 20 Potato Clones and in Vitro Evaluation of Antioxidant, Cholesterol Uptake, and Neuroprotective Activities. Food Chemistry, 133, 1177-1187. http://dx.doi.org/10.1016/j.foodchem.2011.08.065

[44] Igoumenidis, P.E., Konstanta, M.A., Salta, F.N. and Karathanos, V.T. (2011) Phytosterols in Frying Oils: Evaluation of Their Absorption Inpre-Fried Potatoes and Determination of Their Destructionkinetics after Repeated Deep and Pan Frying. Procedia Food Science, 1, 608-615. http://dx.doi.org/10.1016/j.profoo.2011.09.092

[45] Niazmanda, R., Farhoosh, R., Razavi, S.M.A., Mousavic, S.M. and Noghabi, M.S. (2011) Investigation of Quality and Stability of Canola Oil Refined Byadding Chemical Agents and Membrane Processing. Procedia Food Science, 1, 90-94. http://dx.doi.org/10.1016/j.profoo.2011.09.015

[46] Buettner, R., Schölmerich, J., and Bollheimer, C. (2007) High-Fat Diets: Modeling the Metabolic Disorders of Human Obesity in Rodents. Obesity (Silver Spring), 15, 798-808. http://dx.doi.org/10.1038/oby.2007.608

[47] Bansal, G., Zhou, W., Tan, T-W., Neo, F-L. and Lo, H.-L. (2009) Analysis of Trans Fatty Acids in Deep Frying Oils by Three Different Approaches. Food Chemistry, 116, 535-541. http://dx.doi.org/10.1016/j.foodchem.2009.02.083

[48] Choe, E. and Min, D.B. (2007) Chemistry of Deep-Fat Frying Oils. Journal of Food Science, 72, R77-R86. http://dx.doi.org/10.1111/j.1750-3841.2007.00352.x

[49] Bou, R., Navas, J.A., Tres, A., Codony, R. and Guardiola, F. (2012) Quality Assessment of Frying Fats and Fried Snacks during Continuous Deep-Fat Frying at Different Large-Scale Producers. Food Control, 27, 254-267. http://dx.doi.org/10.1016/j.foodcont.2012.03.026

[50] Soupas, L., Huikko, L., Lampi, A.-M. and Piironen, V. (2007) Pan-Frying May Induce Phytosterol Oxidation. Food Chemistry, 101, 286-297. http://dx.doi.org/10.1016/j.foodchem.2006.01.035

[51] Tabee, E., Azadmard-Damirchia, S., Jagerstada, M. and Dutta, P.C. (2008) Lipids and Phytosterol Oxidation in Commercial French Fries Commonly Consumed in Sweden. Journal of Food Composition and Analysis, 21, 169-177. http://dx.doi.org/10.1016/j.jfca.2007.09.008

[52] Tabee, E., Margaretha J. and Dutta, P.C. (2008) Lipids and Phytosterol Oxidation Products in Commercial Potato Crisps Commonly Consumed in Sweden. European Food Research Technology, 227, 745-755. http://dx.doi.org/10.1007/s00217-007-0783-9

[53] Caldas, E.D., Oliveira, J. and Andreia, N. (2011) Exposure to Toxic Chemicals in the Diet: Is the Brazillian Population at Risk. Journal of Exposure Science and Environmental Epidemiology, 22, 1-15. http://dx.doi.org/10.1038/jes.2011.35

[54] Elizabeta, M. (2011) Consumer Protection and Food Safety. Revija za Kriminalistiko in Kriminologijo, 62, 3-11.

[55] Kücükatay, V., Genç, O., Kocamaz, E., Emmungil’, G., Erken, H.A. and Bagci, H. (2008) Spinal Reflexes in Normal and Sulfite Oxidase Deficient Rats: Effect of Sulfite Exposure. Toxicology and Industrial Health, 24, 147-153. http://dx.doi.org/10.1177/0748233708092225

[56] Oner, M.E. and Walker, P.N. (2011) Effect of Processing and Packaging Conditions on Quality of Refrigerated Potato Strips. Journal of Food Science, 76, 2011. http://dx.doi.org/10.1111/j.1750-3841.2010.01937.x

[57] Poorniamma, R., Gunasekaran, S. and Ariharasivakumar, G. (2011) Toxicity Evaluation of Fungal Food Colorant from Thymomyces Sp. in Albino Mice. Journal of Scientific and Industrial Research, 70, 773-777.

[58] Adriana, S.-V., Ashley, G., Jack, N.L., Xu, Z.M. and Finley, J.W. (2012) Evolution of Phenolic Compounds from Color and Flavor Problems to Health Benefits. Journal of Agricultural and Food Chemistry, 60, 6658-6677. http://dx.doi.org/10.1021/jf300861c

[59] Meldrum, R.J., Little, C.L., Sagoo, S., Mithani, V., McLauchlin, J. and de Pinna, E. (2009) Assessment of the Microbiological Safety of Salad Vegetables and Saucesfrom Kebab Take-Away Restaurants in the United Kingdom. Food Microbiology, 26, 573-577. http://dx.doi.org/10.1016/j.fm.2009.03.013

[60] Sagoo, S.K., Little, C.L., Greenwood, M., Mithani, V., Grant, K.A., McLauchlin, J., de Pinna, E. and Threlfall, E.J. (2009) Assessment of the Microbiological Safety of Dried Spices and Herbs Fromproduction and Retail Premises in the United Kingdom. Food Microbiology, 26, 39-43. http://dx.doi.org/10.1016/j.fm.2008.07.005

[61] Vigil, K.J., Jiang, Z.-D., Chen, J.J., Palumbo, K.L., Galbadage, T., Brown, E.L., Yiang, J., Koo, H., DuPont, M., Ericsson, C., Adachi, J.A. and DuPont, H. (2009) Coliform and Escherichia coli Contamination of Desserts Served in Public Restaurants from Guadalajara, Mexico, and Houston, Texas. American Journal of Tropical Medicine and Hygiene, 80, 606-608.

[62] Muinde, O.K. and Kuria. E. (2005) Hygienic and Sanitary Practices of Vendors of Street Foods in Nairobi, Kenya. 
African Journal of Food Agriculture and Nutritional Development, 5, 1-14.

[63] Halford, N.G., Curtis, T.Y., Muttucumaru, N., Postles, J., Elmore, S.J. and Mottram, D.S. (2012) The Acrylamide Problem: A Plant and Agronomic Science Issue. Journal of Experimental Botany, 63, 2841-2851. http://dx.doi.org/10.1093/jxb/ers011

[64] Ghanayem, B.I., Witt, K.L., El-Hadri, L., Hoffler, U., Kissling, G.E., Shelby, M.D. and Bishop, J.B. (2005) Comparison of Germ Cell Mutagenicity in Male CYP2E1-Null and Wild Type Mice Treated with Acrylamide: Evidence Supporting a Glycidamide Mediated Effect. Biology of Reproduction, 72, 157-163. http://dx.doi.org/10.1095/biolreprod.104.033308

[65] Khalil, F.A. and Aziem, B.A. (2005) Effect of Dietary Acrylamide Formed in Potato Crisps and Toasted Bread on Rats. Egyptian Journal of Natural Toxins, 2, 57-70.

[66] Mestdagh, F., Lachat, C., Katleen Baert, K., Moons, E., Kolsteren, P., Van Peteghem, C. and Bruno De Meulenaer, B. (2007) Importance of a Canteen Lunch on the Dietary Intake of Acrylamide. Molecular Nutrition Food Research, 51, 509-516. http://dx.doi.org/10.1002/mnfr.200600253

[67] Ogolla, J.A., Abong', G.O., Okoth, M.O., Imungi, J.K., Kabira J.N. and Paul Karanja, N. (2012) Levels of Acrylamide in Commercial Potato Crisps Sold in Nairobi, Kenya. Proceedings of the 7th Egerton University International Conference: Research and Expo, Njoro, 26-28 September 2012, 22.

[68] European Commission (EC) (2010) Recommendation on Investigation into the Levels of Acrylamide in Food. Brussels. http://ec.europa.eu/food/food/chemicalsafety/contaminants/recommendation_10012011_acrylamide_food_en.pdf

[69] Douny, C., Widart, J., Maghuin-Rogister, G., De Pauw, E. and Scippo, M.-L. (2012) Quantification of Acrylamide in various Belgian Potato Products Using Solid Phase Extraction and Liquid Chromatography Tandem Mass Spectrometry Detection. Food and Public Health, 2, 137-141.

[70] Tateo, F., Bononi, M. and Gallone, F. (2010) Acrylamide Content in Potato Chips on the Italian Market Determined by Liquid Chromatography Tandem Mass Spectrometry. International Journal of Food Science and Technology, 45, 629634. http://dx.doi.org/10.1111/j.1365-2621.2009.02176.x

[71] Mojska, H., Gielecinska, I. and Stos, K. (2012) Determination of Acrylamide Level in Commercial Baby Foods and an Assessment of Infant Dietary Exposure. Food and Chemical Toxicology, 50, 2722-2728. http://dx.doi.org/10.1016/j.fct.2012.05.023

[72] Dybing, E. and Sanner, T. (2003) Risk Assessment of Acrylamide in Foods. Toxicological Sciences, 75, 7-15. http://dx.doi.org/10.1093/toxsci/kfg165

[73] Boroushaki, M.T., Nikkhah, E., Kazemi, A., Oskooei, M. and Raters, M. (2010) Determination of Acrylamide Level in Popular Iranian Brands of Potato and Corn Products. Food and Chemical Toxicology, 48, 2581-2584. http://dx.doi.org/10.1016/j.fct.2010.06.011

[74] Tareke, E., Rydberg, P., Karlsson, P., Eriksson, S. and Tornqvist, M. (2002) Analysis of Acrylamide, a Carcinogen Formed in Heated Foodstuffs. Journal of Agricultural and Food Chemistry, 50, 4998-5006. http://dx.doi.org/10.1021/jf020302f

[75] Olmez, H., Tuncay, F., Ozcan, N. and Demirel, S. (2008) A Survey of Acrylamide Levels in Foods from the Turkish Market. Journal of Food Composition and Analysis, 21, 564-568. http://dx.doi.org/10.1016/j.jfca.2008.04.011

[76] Cummins, E., Butler, F., Gormley, R. and Brunton, N. (2008) A Methodology for Evaluating the Formation and Human Exposure to Acrylamide through Fried Potato Crisps. Lebensmittel-Wissenschaft and Technologie, 41, 854-867. http://dx.doi.org/10.1016/j.lwt.2007.05.022

[77] Poçaset, M.F., Jorge C., Oliveira, J., Pereira, R., Brandsch, R. and Hogg, T. (2011) Modelling Migration from Paper into a Food Simulant. Food Control, 22, 303-312. http://dx.doi.org/10.1016/j.foodcont.2010.07.028

[78] Reinas, I., Oliveira, J., Pereira, J., Machado, F. and Poças, M.F. (2012) Migration of Two Antioxidants from Packaging into a Solid Food and into Tenax. Food Control, 28, 333-337. http://dx.doi.org/10.1016/j.foodcont.2012.05.023

[79] Pocas, M. and Hogg, T. (2007) Exposure Assessment of Chemicals from Packaging Materials in Foods: A Review. Trends in Food Science Technology, 18, 219-230. http://dx.doi.org/10.1016/j.tifs.2006.12.008

[80] Foster, E., Mathers, J.C. and Adamson, A.J. (2010) Packaged Food Intake by British Children Aged 0 to 6 Years. Food Additives and Contaminants, 27, 380-388. http://dx.doi.org/10.1080/19440040903367161

[81] Beldì, G., Pastorelli, S., Franchini F. and Simoneau, C. (2012) Time- and Temperature-Dependent Migration Studies of Irganox 1076 from Plastics into Foods and Food Simulants. Food Additives and Contaminants, 29, 836-845. http://dx.doi.org/10.1080/19440049.2011.649304

[82] Bomfim, M.V.J., Zamith, H.P.S. and Abrantes, S.M.P. (2011) Migration of 3-Caprolactam Residues in Packaging Intended for Contactwith Fatty Foods. Food Control, 22, 681-684. http://dx.doi.org/10.1016/j.foodcont.2010.09.017 